\title{
PENGARUH LITERASI KEUANGAN SYARIAH, RELIGIUSITAS DAN PERSEPSI MAHASISWA JABODETABEK TERHADAP KEPUTUSAN MENGGUNAKAN LAYANAN PERBANKAN SYARIAH
}

\author{
Muhammad Ikbal Falevy1), Suryani'2), Prima Dwi Priyatno3) \\ Universitas Pembangunan Nasional Veteran Jakarta \\ 1)muhammad.ikbal@upnvj.ac.id 2) suryapijar@yahoo.com ${ }^{3)}$ primadpriyatno@upnvj.ac.id
}

\begin{abstract}
Abstrak. Industri perbankan syariah telah lama dinantikan oleh segenap masyarakat muslim yang menginginkan sebuah sistem perbankan berlandaskan prinsip syariah di Indonesia. Meskipun kini bank syariah telah hadir, namun masih banyak dinamika yang dihadapi oleh perbankan syariah. Penelitian ini bertujuan untuk menjabarkan pengaruh dari literasi keuangan syariah, religiusitas dan persepsi mahasiswa jabodetabek terhadap keputusan menggunakan layanan perbankan syariah. Metode riset yang digunakan dalam penelitian ini berjenis kuantitatif dengan metode pengumpulan data menggunakan metode purposive sampling dengan jumlah sampel sebanyak 181 responden yang disebarluaskan kepada para mahasiswa yang menggunakan perbankan syariah di Jabodetabek melalui kuesioner. Teknik analisis data dalam penelitian ini adalah uji validitas, uji reabilitas, uji asumsi klasik, uji regresi linier berganda dan uji hipotesis dengan bantuan peranti lunak Statistical Package for the Social Sciences (SPSS) versi 25. Hasil penelitian ini menunjukan bahwa variabel literasi keuangan syariah, religiusitas dan persepsi mahasiswa jabodetabek memiliki pengaruh yang positif dan signifikan terhadap keputusan menggunakan layanan perbankan syariah.
\end{abstract}

Kata kunci : Literasi keuangan syariah, religiusitas, persepsi, perbankan syariah.

\begin{abstract}
The Islamic banking industry has long been awaited by all Muslim communities who want a banking system based on sharia principles in Indonesia. Even though Islamic banks are now present, there are still many dynamics faced by Islamic banking. This study aims to describe the influence of Islamic financial literacy, religiosity and perceptions of Jabodetabek students on decisions to use Islamic banking services. The research method used in this research is quantitative with data collection method using purposive sampling method with a total sample of 181 respondents who are distributed to students who use Islamic banking in Jabodetabek through questionnaires. The data analysis techniques in this study were validity tests, reliability tests, classical assumption tests, multiple linear regression tests and hypothesis testing with the help of the Statistical Package for the Social Sciences (SPSS) software version 25. The results of this study indicate that the Islamic financial literacy variable, religiosity and perceptions of Jabodetabek students have a positive and significant influence on the decision to use Islamic banking services.
\end{abstract}

Keywords: Islamic financial literacy, religiosity, perception, Islamic banking. 


\section{PENDAHULUAN}

Eksistensi industri perbankan syariah di Indonesia sudah melewati horizon sejarah yang panjang panjang dan memiliki dinamikanya tersendiri. Bank Syariah di Indonesia terutama Bank Muamalat Indonesia (BMI) telah beberapa kali memperlihatkan eksistensi dan resistansinya dalam menghadapi krisis moneter yang telah terjadi. Perbankan Syariah tetap konsisten dalam memberikan jasa, profit, kenyamanan serta keamanan kepada nasabahnya, bahkan pada krisis keuangan tahun 2008 pun BMI mampu mencatatkan laba lebih dari Rp 300 miliar. Peristiwa ini dapat dijadikan sebuah momentum dan indikasi bahwa industri perbankan syariah mampu tumbuh dengan signifikan dimasa yang akan datang1. Data terbaru yang didapat dari statistik perbankan syariah oleh Otoritas Jasa Keuangan mencatatkan jumlah nasabah perbankan syariah pada bulan januari 2021 menyentuh angka 36,7 juta rekening nasabah. Masih terbilang jauh jika dilihat dari total keseluruhan masyarakat muslim di Indonesia yakni 229 juta jiwa, masih ada 192,3\% potensi yang belum terjamah oleh perbankan syariah. Begitupun dengan jumlah nasabah milenial yang menggunakan perbankan syariah masih belum diketahui, Bank Syariah di Indonesia.

Peranan SDM mahasiswa muslim Indonesia dalam membangun eskalasi gerakan ekonomi Islam dirasa sangatlah penting. Keunggulan mereka dalam penguasaan teknologi dan informasi akan menjadi nilai tambah terhadap upaya penyebarluasan tentang sistem ekonomi dan keuangan syariah nantinya haruslah menyasar minat nasabah baik milenial maupun GenZ untuk menabung pada perbankan syariah. Terdapat beberapa kendala yang menghambat pertumbuhan perbankan syariah di Indonesia, kendala tersebut meliputi tingkat literasi keuangan syariah, religiusitas dan persepsi yang menjangkiti perbankan syariah. Penelitian sebelumnya oleh Rachmatulloh menyebutkan dalam penelitiannya bahwa variabel literasi keuangan berpengaruh secara signifikan terhadap keputusan untuk menabung di perbankan syariah². Sedangkan penelitian yang dilakukan oleh Khosasi, beliau menyebutkan bahwa jika literasi keuangan syariah terdapat perkembangan maka keputusan menggunakan produk perbankan syariah juga turut berkembang33. Hasil kontradiktif ditunjukan oleh Yulianto dalam

${ }^{1}$ Andrew Shandy Utama, “Perkembangan Perbankan Syariah Di Indonesia," UNES Law Review 2, no. 3 (2020): 290-298.

${ }^{2}$ Dhepril Puradi Rachmatulloh, "Pengaruh Literasi Keuangan Syariah, Religiusitas Dan Kualitas Pelayanan Terhadap Keputusan Menabung Di Bank Syariah (Studi Pada Generasi Milenial Di Indonesia)” (2020).

${ }^{3}$ Akhsanul Khosasi, "Pengaruh Literasi Keuangan Syariah Dan Pemasaran Terhadap Pengambilan Keputusan Nasabah Melakukan Pembiayaan Mikro Di Bank Syariah Bukopin Sidoharjo" (2017): 1-93. 
hasil penelitiannya yang menunjukkan bahwa literasi keuangan syariah tidak berpengaruh terhadap keputusan menabung di lembaga keuangan syariah4 ${ }^{4}$. Hasil penelitian serupa pun ditunjukan oleh Octavia dalam penelitiannya bahwa secara parsial literasi keuangan syariah tidak berpengaruh terhadap pengambilan keputusan nasabah melakukan pembiayaan mikro ${ }^{5}$.

Penelitian yang dilakukan oleh Iskamto menunjukan hasil positif terhadap variabel religiusitas yang di uji. Meskipun berpengaruh positif namun hasil tersebut tidak secara signifikan6. Penelitian yang dilakukan oleh Zuhirsyan menyatakan bahwa persepsi produk bank syariah memiliki banyak inovasi dan manfaat juga dapat meningkatkan minat mahasiswa untuk menabung di bank syariah. Meskipun mendapat hasil positif, namun dalam penelitiannya menunjukan hasil yang tidak signifikan ${ }^{7}$. Berdasarkan data penelitian terdahulu yang telah dijabarkan di atas, masih terdapat banyak perbedaan hasil penelitian. Sehingga penulis tertantang untuk meneliti lebih lanjut mengenai pengaruh literasi keuangan, religiusitas dan persepsi terhadap keputusan mahasiswa menggunakan perbankan syariah dengan data terbaru yang telah dihimpun. Rumusan Masalah dalam penelitian ini adalah:

1. Bagaimanakah pengaruh literasi keuangan syariah mahasiswa jabodetabek terhadap keputusan menggunakan layanan perbankan syariah?

2. Bagaimanakah pengaruh religiusitas mahasiswa jabodetabek terhadap keputusan menggunakan layanan perbankan syariah?

3. Bagaimanakah pengaruh persepsi mahasiswa jabodetabek terhadap keputusan menggunakan layanan perbankan syariah?

4. Bagaimanakah pengaruh literasi keuangan syariah, religiusitas dan persepsi mahasiswa jabodetabek secara simultan terhadap keputusan menggunakan layanan perbankan syariah?

\footnotetext{
${ }^{4}$ Agus Yulianto, "PENGARUH LITERASI KEUANGAN SYARIAH TERHADAP KEPUTUSAN PENGGUNAAN PRODUK ATAU JASA LEMBAGA KEUANGAN SYARIAH" 10, no. 2 (October 2018): 1-15.

${ }^{5}$ Anggraini Octavia, PENGARUH LITERASI KEUANGAN SYARIAH DAN PEMASARAN TERHADAP PENGAMBILAN KEPUTUSAN NASABAH MELAKUKAN PEMBIAYAAN MIKRO DI BANK WAKAF MIKRO MAWARIDUSSALAM, Journal of Chemical Information and Modeling, vol. 53, 2020.

6 Dedi Iskamto, “Analisis Peranan Religiusitas Terhadap Kepercayaan Kepada Perbankan Syariah” (n.d.).

7 Muhammad Zuhirsyan, "Pengaruh Religiusitas Dan Persepsi Nasabah Terhadap Keputusan Memilih Bank Syariah" 10, no. 1 (2018): 48-62.
} 


\section{METODE PENELITIAN}

\section{Jenis dan Pendekatan Penelitian}

Penelitian ini memakai prosedur riset kuantitatif sebagai pendekatan disertai dengan uji regresi linier berganda, analisis deskriptif, uji realibilitas, uji asumsi klasik dan uji hipotesis dibantu dengan perangkat lunak SPSS versi 25.

\section{Variabel Penelitian}

Penelitian ini terdapat tiga variabel bebas, yaitu literasi keuangan syariah (X1), religiusitas (X2) dan persepsi (X3) mahasiswa jabodetabek yang akan di analisis pengaruh variabel tersebut terhadap variabel terikat dalam penelitian ini yaitu keputusan menggunakan layanan perbankan syariah $(\mathrm{Y})$.

\section{Populasi dan Sampel Penelitian}

Populasi yang digunakan pada penelitian ini adalah mahasiswa yang berdomisili pada wilayah Jakarta, Bogor, Depok, Tanggerang dan Bekasi, serta menggunakan bank syariah.. Adapun sampel dalam penelitian ini memakai teknik purposive sampling yang merupakan sebuah metode penghimpunan spesimen yang ditentukan berdasarkan alasan khusus dengan jumlah responden sebanyak minimal 100 orang. (Mardiyana, 2019)

Kriteria sampel yang digunakan pada penelitian ini sebagai berikut:

a. Mahasiswa yang berdomisili pada wilayah Jabodetabek.

b. Mahasiswa pengguna Bank Umum Syariah (BUS).

c. Mahasiswa dengan rentang usia 18-30 tahun.

\section{Sumber Data Penelitian}

Data primer yang diterima bersumber atas peninjauan lokasi penelitian. Peneliti melangsungkan penghimpunan informasi melalui pengedaran angket kepada calon responden yang menjadi sasaran dikarenakan sumber informasi yang di perlukan bersifat primer. Kuesioner tersebut di sebarkan kepada para mahasiswa yang mengetahui atau menggunakan produk dan jasa perbankan syariah di Jabodetabek melalui perantara google form atau aplikasi serupa lainnya. Penelitian ini memakai prosedur riset kuantitatif sebagai pendekatan disertai dengan uji regresi linier berganda, analisis deskriptif, uji realibilitas, uji asumsi klasik dan uji hipotesis dibantu dengan perangkat lunak SPSS versi 25. Peneliti akan mengelompokkan data berdasarkan variabel dari setiap responden dan setelah itu dilakukukan penghitungan untuk menjawab pertanyaan di rumusan masalah setelah proses pengumpulan data selesai. Metode 
analisis data juga diperlukan untuk menguji asumsi yang ingin diteliti dan digunakan untuk mengetahui korelasi antara variabel bebas (X1, X2, X3) terhadap variabel terikat (Y).

\section{Hipotesis Penelitian}

Hipotesis dalam penelitian ini adalah:

1. Ha1 : Variabel literasi keuangan syariah mahasiswa jabodetabek berpengaruh secara signifikan terhadap keputusan menggunakan layanan perbankan syariah.

2. Ha2 : Variabel religiusitas mahasiswa jabodetabek berpengaruh secara signifikan terhadap keputusan menggunakan layanan perbankan syariah.

3. Ha3 : Variabel persepsi mahasiswa jabodetabek berpengaruh secara signifikan terhadap keputusan menggunakan layanan perbankan syariah.

4. Ha1,2,3 : Variabel literasi keuangan, religiusitas dan persepsi mahasiswa jabodetabek berpengaruh secara simultan dan signifikan terhadap keputusan menggunakan layanan perbankan syariah.

\section{HASIL DAN PEMBAHASAN}

\section{I.1 Pengertian Literasi Keuangan Syariah}

literasi keuangan syariah adalah keahlian, perbuatan, kapabilitas dan kompetensi seseorang berkenaan dengan pengelolaan sumber daya keuangan, sesuai dengan kaidah syariat Islam. Selain itu, literasi keuangan syariah adalah suatu keharusan bagi setiap muslim agar membawa keterkaitan lebih lanjut tentang realisasi kesuksesan sejati baik diakhirat maupun didunia ${ }^{8}$. literasi keuangan syariah adalah sebuah pengetahuan yang masyarakat miliki yang sesuai dengan syariat Islam tentang cara mengelola dana. Sehingga hal tersebut dapat mengubah sikap dan perilaku masyarakat dalam mengelola keuangan serta dapat menyejahterakan hidupnya ${ }^{9}$.

Sejalan dengan definisi literasi keuangan syariah diatas, bahwa literasi keuangan syariah adalah sebuah perkara yang krusial sekaligus fundamental yang perlu dimiliki oleh setiap muslim demi mencapai kesejahteraan sejati sesuai dengan firman Allah swt. dalam QS

${ }^{8}$ Yulianto, "PENGARUH LITERASI KEUANGAN SYARIAH TERHADAP KEPUTUSAN PENGGUNAAN PRODUK ATAU JASA LEMBAGA KEUANGAN SYARIAH.”

${ }^{9}$ Nurus Shobah, "Analisis Literasi Keuangan Syariah Terhadap Penggunaan Jasa Perbankan Syariah Sebagai Upaya Meningkatkan Sharia Financial Inclusion(Studi Pada Mahasiswa Ekonomi Syariah UIN Sunan Ampel Surabaya)," UIN Sunan Ampel Surabaya (2017). 
Al Mujadalah: 11. yang menjadi landasan hukum untuk menghilangkan segala transaksi yang bathil dalam Islam, surah tersebut berbunyi:

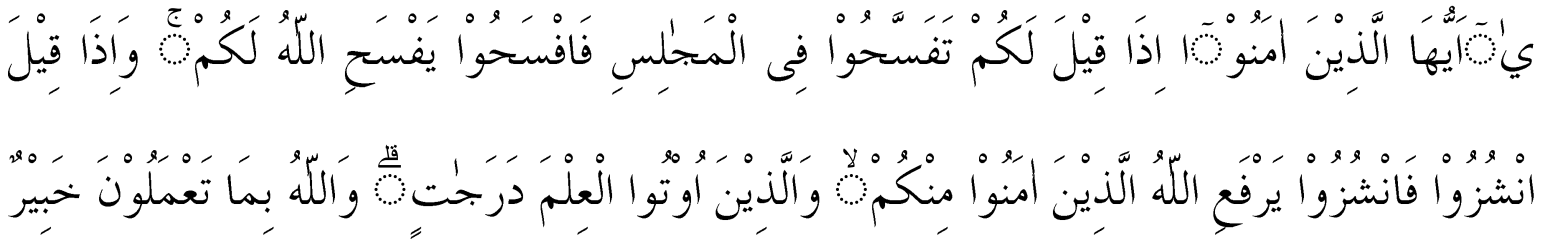

Artinya: "Wahai orang-orang yang beriman, apabila dikatakan kepadamu Berilah kelapangan di dalam majelis-majelis, lapangkanlah, niscaya Allah akan memberi kelapangan untukmu. Apabila dikatakan, Berdirilah, (kamu) berdirilah. Allah niscaya akan mengangkat orang-orang yang beriman di antaramu dan orang-orang yang diberi ilmu beberapa derajat. Allah Mahateliti terhadap apa yang kamu kerjakan". (QS. AlMujadalah : 11)

Syeikh Muhammad bin Shalih Asy-Syawi menafsirkan ayat diatas sebagai keutamaan dalam sebuah pengetahuan. Pengetahuan dapat membuahkan adab yang baik dalam menerapkan ilmu-ilmu tersebut. Sehingga dengan seiring bertambahnya tingkat pemahaman akan pengelolaan keuangan, kaum muslimin diharapkan dapat menjadikan ilmu dan adab tersebut menjadi sebuah acuan dalam bertransaksi dalam proses mendapatkan hingga menggunakan uang.

\section{I.2 Religiusitas}

Religiusitas menurut Adiwarman Karim dalam Rachmatullah (2020) adalah suatu bentuk dimensi religi yang dimaknai oleh setiap individu didalam sanubari mereka. Esensi sebuah religusitas dapat diinterpretasikan dalam beberapa aspek yang harus dipatuhi guna mendapatkan kebaikan pada dunia maupun akhirat. Islam adalah sebuah agama yang komprehensif dimana seluruh dimensi dalam kehidupan baik itu hubungan dengan manusia, semesta maupun dengan Allah swt. Semua telah diatur pada koridor akidah, syariah dan akhlak ${ }^{10}$. Religiusitas merupakan sebuah hierarki yang mengoneksikan antara dogma, agama dan keimanan seorang individu dalam melaksanakan perintah agama yang diimplementasikan pada bermacam aspek kehidupan termasuk dalam berekonomi ${ }^{11}$.

\footnotetext{
${ }^{10}$ Rachmatulloh, "Pengaruh Literasi Keuangan Syariah, Religiusitas Dan Kualitas Pelayanan Terhadap Keputusan Menabung Di Bank Syariah (Studi Pada Generasi Milenial Di Indonesia).”

11 Pandu Tezar Adi Nugroho Fajar Mujaddid, "PENGARUH PENGETAHUAN, REPUTASI, LINGKUNGAN DAN RELIGIUSITAS TERHADAP MINAT PELAJAR SEKOLAH MENENGAH KEJURUAN PRODI PERBANKAN SYARIAH DALAM MENABUNG DI BANK SYARIAH," Jurnal Ekonomi Islam 10 (2019).
} 


\section{I.3 Persepsi}

Persepsi dapat didefinisikan melalui pendekatan secara harfiah yang berasal dari kata perception dalam bahasa Inggris dan bahasa latin yakni percipare yang memiliki makna menerima atau mengambil ${ }^{12}$.

Berdasarkan kamus lengkap psikologi, persepsi diinterpretasikan sebagai:

1. Metode untuk mengidentifikasikan suatu fenomena dengan dukungan panca indera.

2. Suatu himpunan proses penginderaan dengan interpolasi makna berdasarkan pengalaman di masa lampau.

3. Variabel yang menjadi penghambat bermula dari kapabilitas sebuah sistem dalam membedakan rangsangan yang masuk.

4. Kesadaran naluriah berkenaan dengan fakta spontan atau ketetapan hati mengenai suatu fenomena ${ }^{13}$.

Persepsi pada dasarnya adalah sebuah pengalaman psikologis yang dilewati oleh setiap manusia untuk mengilhami tiap fakta tentang sekitarnya melalui proses penginderaan yang dimilikinya. Taktik untuk menafsirkan sebuat persepsi terletak pada pemahaman bahwa persepsi itu adalah suatu interpretasi yang spesial terhadap fenomena ${ }^{14}$.

\section{I.4 Mahasiswa}

Mahasiswa adalah perseorangan yang sedang menimba ilmu pada perguruan tinggi baik swasta maupun negeri dengan karakteristik kematangan usia dan pola pikir, serta cepat tanggap mengenai sesuatu ${ }^{15}$.

Mahasiswa dapat dikatakan sedang dalam masa pertumbuhan adalah ketika ia berusia 18 - 25 tahun. Proses ini dapat disebut sebagai tahapan awal dalam kedewasaan, ditandai dengan dimulainya perjalanan hidup dan membuat keputusan secara mandiri ${ }^{16}$.

\section{I.5 Perbankan Syariah}

Perbankan adalah suatu institusi moneter yang bersifat krusial untuk menopang perekonomian suatu negara, semakin maju industri keuangan maka akan sejalan dengan perkembangan ekonomi negara tersebut. Peranan perbankan sebagai institusi moneter

\footnotetext{
12 Alex Sobur, Psikologi Umum (Pustaka Setia, Bandung, 2003).

13 Chaplin, Kamus Psikologi Lengkap (PT. Raja Grafindo Persada, Jakarta, 2008).

14 Zuhirsyan, "Pengaruh Religiusitas Dan Persepsi Nasabah Terhadap Keputusan Memilih Bank Syariah."

15 Dwi Siswoyo, Ilmu Pendidikan (Yogyakarta: UNY Press, 2007).

16 Syamsu Yusuf, Psikologi Perkembangan Anak Dan Remaja (Bandung: Remaja Rosdakarya, 2012).
} 
memiliki fungsi untuk menerima, menyimpan dan menyalurkan kembali simpanan kepada publik dalam upaya desenteralisasi ekonomi, kemajuan dan kestabilan perekonmian nasional dalam rangka meningkatkan kemakmuran masyarakat. Bersumber pada "Undang-Undang RI Nomor 10 Tahun 1998 tanggal 10 November 1998 Tentang Perbankan, yang dimaksud dengan perbankan adalah suatu badan usaha yang bertugas untuk menghimpun dana dari masyarakat dalam bentuk simpanan dan menyalurkannya kembali dalam bentuk kredit dan atau bentukbentuk lainnya dalam rangka meningkatkan taraf hidup yang lebih layak bagi rakyat banyak ${ }^{17 . "}$ Perbankan syariah berdasarkan Undang-undang “Peraturan Bank Indonesia Pasal 2 PBI No. 6/24/PBI/2004 adalah suatu lembaga perbankan yang melaksanakan kegiatan usaha berdasarkan prinsip syariah yang dalam kegiatannya memberikan jasa dalam lalu lintas pembayaran. Berdasarkan Undang-undang nomor 21 tahun 2008 tentang Perbankan Syariah, bank syariah adalah bank yang menjalankan kegiatan usahanya berdasarkan prinsip syariah dan menurut jenisnya terdiri atas Bank Umum Syariah (BUS) dan Bank Pembiayaan Rakyat Syariah (BPRS)."

Harahap mendefinisikan bahwa bank syariah adalah bank yang memiliki sistem operasional yang memberikan layanan bebas riba kepada nasabahnya atau dengan kata lain menjadi sistem perbankan yang patuh pada kaidah dan prinsip syariat agama Islam sebagai landasan fundamental dan hukumnya. Segala perjanjian baik imbalan yang diperoleh atau dibagikan oleh bank kepada nasabah tergantung pada perjanjian awal yang telah disepakati ${ }^{18}$.

\section{Paparan Hasil Penelitian}

Berikut merupakan hasil perhitungan data deskriptif yang telah dikolektifkan berdasarkaan faktor dan parameter yang telah ditentukan:

\section{1) Uji Statistik Deskriptif}

Tabel 1

Analisis Deskriptif Variabel

\begin{tabular}{|c|c|c|c|c|c|}
\hline \multicolumn{6}{|c|}{ Statistics } \\
\hline $\mathrm{N}$ & Valid & $\mathrm{X} 1$ & $\mathrm{X} 2$ & $\mathrm{X} 3$ & $\mathrm{Y}$ \\
\hline \multicolumn{2}{|c|}{181} & 181 & 181 & 181 \\
\hline
\end{tabular}

17 Kasmir, Bank Dan Lembaga Keuangan Syariah (PT. Raja Grafindo Persada, Jakarta, 2009).

18 Novia Melati Harahap, ANALISIS FAKTOR-FAKTOR YANG MEMPENGARUHI MINAT GENERASI MILENIAL JABODETABEK MEMILIH BANK SYARIAH, Malaysian Palm Oil Council (MPOC), vol. 21, 2020, http://mpoc.org.my/malaysian-palm-oil-industry/. 


\begin{tabular}{|l|r|r|r|r|}
\hline \multicolumn{1}{|c|}{$\begin{array}{l}\text { Missin } \\
\mathrm{g}\end{array}$} & 0 & 0 & 0 & 0 \\
\hline Mean & 56,67 & 36,16 & 12,81 & 20,91 \\
\hline Median & 57,00 & 37,00 & 13,00 & 21,00 \\
\hline Std. Deviation & 7,029 & 3,739 & 1,940 & 3,097 \\
\hline Variance & 49,412 & 13,980 & 3,765 & 9,592 \\
\hline Range & 33 & 17 & 9 & 16 \\
\hline Minimum & 37 & 23 & 6 & 9 \\
\hline Maximum & 70 & 40 & 15 & 25 \\
\hline
\end{tabular}

Sumber: Hasil pengolahan data SPSS 25

Hasil pengolahan data diatas menunjukaan bahwa variabel X1 memiliki rata-rata sebesar 56,67 dengan standar deviasi 7,02. Hal ini mengindikasikan bahwa standar deviasi X1 lebih kecil dari nilai rata-rata sehingga terdapat hasil yang baik dari 9variable literasi keuangan syariah. Begitupun untuk juga untuk 9ariable religiusitas dan persepsi.

\section{2) Uji Reabilitas}

Uji reabilitas dipergunakan untuk menakar tingkat kestabilan tiap variabel penelitian. Kusioner dikatakan reliabel apabila dicoba berulang kali di himpunan yang sama maka akan diperoleh data yang selaras, sehingga dapat diasumsikan tidak ditemukan perbedaan kognitif pada subjek penelitian. Suatu variabel penelitian dapat dikatakan reliabel jika kaidah cronbach alpha $>0,60$ terpenuhi.

Tabel 2

Uji Reabilitas Variabel

\begin{tabular}{|l|c|c|c|}
\hline \multicolumn{1}{|c|}{ Variabel } & Cronbach Alpha & $\begin{array}{c}\text { Nilai } \\
\text { Kritis }\end{array}$ & Keputusan \\
\hline $\begin{array}{l}\text { Literasi Keuangan } \\
\text { Syariah }\end{array}$ & 0,844 & 0,60 & Reliabel \\
\hline Religiusitas & 0,840 & 0,60 & Reliabel \\
\hline Persepsi & 0,828 & 0,60 & Reliabel \\
\hline $\begin{array}{l}\text { Keputusan } \\
\text { Menggunakan } \\
\text { Layanan Perbankan } \\
\text { Syariah }\end{array}$ & 0,849 & 0,60 & Reliabel \\
\hline $\begin{array}{l}\text { Sumber: Data diolah, 2021 } \\
\text { Singer }\end{array}$ & & \\
\hline
\end{tabular}

Berlandaskan pada data pada tabel tersebut, dapat diambil kesimpulan bahwa semua variabel bebas baik dari literasi keuangan syariah, religiusitas, persepsi dan keputusan memiliki nilai cronbach alpha $>60$, sehingga data dapat dikatakan reliabel untuk melakukan penelitian selanjutnya. 


\section{3) Uji Normalitas}

Menurut Gujarati dan Porter, uji normalitas adalah sebuah metode yang berfungsi untuk menakar apakah dalam model regresi tersebut terdapat nilai distribusi normal atau tidak sebelum dilaksanakan pengujian hipotesis ${ }^{19}$. Metode yang diperlukan untuk melihat apakah data terdistibusi normal dapat menggunakan tabel normal One-Sample KolmogorovSmirnov Test berdasarkan probabilitas Monte Carlo, bila nilai probabilitas $>$ 0,05 maka distribusi dari regresi dinyatakan normal.

Tabel 3

Uji Normalitas Variabel

\begin{tabular}{|c|c|c|c|}
\hline \multicolumn{4}{|c|}{ One-Sample Kolmogorov-Smirnov Test } \\
\hline & & & $\begin{array}{c}\text { Unstandardized } \\
\text { Residual }\end{array}$ \\
\hline \multicolumn{3}{|l|}{$\mathrm{N}$} & 181 \\
\hline \multirow[t]{2}{*}{ Normal Parameters ${ }^{\mathrm{a}, \mathrm{b}}$} & \multicolumn{2}{|l|}{ Mean } & .0000000 \\
\hline & \multicolumn{2}{|l|}{ Std. Deviation } & 2.16946942 \\
\hline \multirow[t]{3}{*}{ Most Extreme Differences } & \multicolumn{2}{|l|}{ Absolute } & .075 \\
\hline & \multicolumn{2}{|l|}{ Positive } & .060 \\
\hline & \multicolumn{2}{|l|}{ Negative } & -.075 \\
\hline \multicolumn{3}{|l|}{ Test Statistic } & .075 \\
\hline \multirow{3}{*}{$\begin{array}{l}\text { Monte Carlo Sig. (2- } \\
\text { tailed) }\end{array}$} & \multicolumn{2}{|l|}{ Sig. } & $.243^{\mathrm{d}}$ \\
\hline & \multirow[t]{2}{*}{$\begin{array}{l}95 \% \text { Confidence } \\
\text { Interval }\end{array}$} & $\begin{array}{l}\text { Lower } \\
\text { Bound }\end{array}$ & .181 \\
\hline & & $\begin{array}{l}\text { Upper } \\
\text { Bound }\end{array}$ & .306 \\
\hline
\end{tabular}

Sumber: Data diolah, 2021

Berlandaskan pada data tabel pengujian diatas didapatkan hasil bahwa angka signifikansi Monte Carlo Sig. (2-tailed) berada pada angka 0,243>0,05, oleh karena itu disimpulkan bahwa item dalam penelitian ini memiliki residual yang terdistribusi normal.

\section{4) Uji Linieritas}

Uji liniearitas berfungsi untuk menemukan korelasi linier antara variabel baik bebas maupun terikat. Jika terbukti ada hubungan yang linier maka peneliti dapat menggunakan analisis regresi linier. Apabila tidak ditemukan maka peneliti akan menggunakan analisis non linier.

\footnotetext{
${ }^{19}$ Gujarati and Porter, Dasar-Dasar Ekonometrika, 5th ed. (Salemba Empat, 2015).
} 
Tabel 4

Uji Linieritas Variabel

\begin{tabular}{|l|c|}
\hline \multicolumn{1}{|c|}{ Variabel } & Sig. \\
\hline Literasi Keuangan Syariah & 0,796 \\
\hline Religiusitas & 0,113 \\
\hline Persepsi & 0,902 \\
\hline
\end{tabular}

Sumber: Data diolah, 2021

Bersumber pada data tabel linearitas diatas, nilai signifikansi yang diperoleh dari literasi keuangan syariah (X1) yaitu sebesar 0,796. Hal ini menunjuklan bahwa nilai tersebut berada diatas $>0,05$. Berdasarkan data diatas diperoleh hasil bahwa hubungan antara variabel literasi keuangan syariah, religiusitas dan persepsi terhadap keputusan menggunakan layanan perbankan syariah adalah linier.

\section{5) Uji Heteroskedastisitas}

Uji heterokedastisitas merupakan sebuah metode pengujian yang berfungsi untuk mengukur apakah dalam suatu bentuk regresi terdapat ketidakselarasan variance dalam suatu pengamatan ke pengamatan selanjutnya atau dengan kata lain residual dari bentuk tersebut tidak memiliki varians yang stabil dan tetap ${ }^{20}$. Apabila nilai probabilitas (sig) $>0,05$ maka tidak ada heteroskedastisitas.

Tabel 5

Uji Heteroskedastisitas Variabel

\begin{tabular}{cc}
\hline Variabel & Sig. \\
\hline Literasi Keuangan Syariah & 0,285 \\
\hline Religiusitas &, 0819 \\
\hline Persepsi & 0,704 \\
\hline
\end{tabular}

Sumber: Data diolah, 2021

Bersumber pada hasil olah data dalam tabel 22 diatas dapat diperoleh hasil pengujian nilai dari tiap variabel berada level signifikansi diatas 0,05. Berlandaskan pada data diatas dapat diartikan bahwa tidak terdapat gejala heterokedastisitas dalam tiap variabel dalam penelitian ini.

\section{6) Uji Multikolinieritas}

Uji multikolinearitas merupakan sebuah metode pengujian untuk melihat apakah adanya korespondensi yang kuat sesama variabel bebas. Bentuk regresi yang ideal dapat

${ }^{20}$ Roger Bougie Uma Sekaran, Metode Penelitian Untuk Bisnis, 6th ed. (Salemba Empat, 2017). 
diketahui dari nilai variane inflation factor (VIF) dan tolerance. Pedoman yang digunakan dalam suatu bentuk regresi yang tidak terdeteksi multikolinearitas adalah memperoleh angka tolerance 0,10 dan nilai VIF dibawah 10.

Tabel 6

Uji Multikolinieritas Variabel

\begin{tabular}{|c|c|c|}
\hline Variabel & Tolerance & VIF \\
\hline Literasi Keuangan Syariah & .588 & 1.702 \\
\hline Religiusitas & .585 & 1.711 \\
\hline Persepsi & .505 & 1.979 \\
\hline
\end{tabular}

Sumber: Data diolah, 2021

Bersumber pada hasil uji multikolinearitas diatas, diketahui bahwa angka toleransi pada masing-masing variabel bebas berada diatas 0,10 dan nilai VIF pada setiap variabel bebas berada pada angka dibawah 10. Berlandaskan pada pedoman pengambilan keputusan multikolinearitas, variabel tersebut dinyatakan bebas dari gejala.

\section{7) Uji Regresi Linier Berganda}

Penelitian ini memakai prosedur pengujian regresi linier berganda sebagai salah satu metode telaah data, dengan tujuan memperoleh data hubungan antara variabel literasi keuangan syariah, religiusitas dan persepsi terhadap keputusan konsumen milenial dalam menggunakan perbankan syariah melalui persamaan matematis apakah signifikan atau tidak.

Tabel 7

Anova

\begin{tabular}{|l|l|r|r|r|r|r|}
\hline \multicolumn{2}{|l|}{ Model } & \multicolumn{1}{c|}{$\begin{array}{c}\text { Sum of } \\
\text { Squares }\end{array}$} & \multicolumn{1}{c|}{ df } & \multicolumn{1}{c|}{$\begin{array}{c}\text { Mean } \\
\text { Square }\end{array}$} & F & Sig. \\
\hline \multirow{2}{*}{1} & Regression & 879.398 & 3 & 293.133 & 61.243 & $.000^{\mathrm{b}}$ \\
\cline { 2 - 7 } & Residual & 847.188 & 177 & 4.786 & & \\
\cline { 2 - 7 } & Total & 1726.586 & 180 & & & \\
\hline
\end{tabular}

Sumber: Data diolah, 2021

Tabel 8

Koefisien Uji Linier Berganda

\begin{tabular}{|c|c|c|c|c|c|c|}
\hline \multirow{2}{*}{\multicolumn{2}{|c|}{ Model }} & \multicolumn{2}{|c|}{$\begin{array}{c}\text { Unstandardized } \\
\text { Coefficients }\end{array}$} & \multirow{2}{*}{$\begin{array}{c}\text { Standardized } \\
\text { Coefficients }\end{array}$} & \multirow[t]{2}{*}{$\mathrm{t}$} & \multirow[t]{2}{*}{ Sig. } \\
\hline & & $\mathrm{B}$ & Std. Error & & & \\
\hline 1 & (Constant) & 1.285 & 1.689 & & $\begin{array}{r}.76 \\
1 \\
\end{array}$ & .448 \\
\hline
\end{tabular}


Volume 3, Nomor 1 / Januari 2022

\begin{tabular}{|l|l|r|r|r|r|r|}
\hline $\begin{array}{l}\text { Literasi Keuangan } \\
\text { Syariah }\end{array}$ & .063 & .030 & .143 & 2.0 & .039 \\
\cline { 2 - 6 } & Religiusitas & .196 & .057 & .237 & 3.4 & .001 \\
& Persepsi & .700 & .118 & .439 & 5.9 & .000 \\
\hline
\end{tabular}

Sumber: Data diolah, 2021

Bersumber pada informasi pada tabel 27 dapat dilihat bahwa jumlah $\mathrm{F}_{\text {hitung }}$ sebesar 61.243 dengan derajat penerimaan kurang dari 0,05. Bersumber pada informasi tersebut, maka dapat ditarik kesimpulan bahwa terdapat dampak yang signifikan antar item variabel literasi keuangan syariah (X1), religiusitas (X2), persepsit (X3), terhadap keputusan menggunakan layanan perbankan syariah (Y). Berlandaskan data analisis pada tabel 28 dapat diperoleh hasil pengujian regresi linier berganda menghasilkan rumus statisktik sebagai berikut:

$$
Y=1,285+0,063 x_{1}+0,196 x_{2}+0,700 x_{3}+e
$$

Bersumber pada nilai persamaan matematika diatas, interpretasinya adalah sebagai berikut:

1. Nilai konstanta (a) sebesar 1,285. Mengindikasikan apabila koefisien regresi pada konstanta adalah sebesar 1,285, hasilnya adalah apabila variabel literasi keuangan syariah, religiusitas, dan persepsi nilainya adalah 0 maka keputusan konsumen milenial meningkat sebesar 1,285.

2. Besaran koefisien variabel literasi keuangan syariah $\left(X_{1}\right)$ bernilai 0,63 . Hasil tersebut dapat diartikan apabila terjadi peningkatan atau penambahan dalam satuan literasi keuangan syariah $\left(\mathrm{X}_{1}\right)$ akan berakibat pada peningkatan keputusan konsumen milenial ( $\mathrm{Y}$ ) sebesar 0,063.

3. Nilai koefisien variabel religiusitas $\left(X_{2}\right)$ sebesar 0,196. Hasil tersebut menginterpretasikan apabila terjadi peningkatan atau penambahan dalam satuan religiusitas $\left(\mathrm{X}_{2}\right)$ akan berakibat pada peningkatan keputusan konsumen milenial (Y) sebesar 0,196.

4. Besaran koefisien variabel persepsi (X3) sebesar 0,700. Hasil tersebut mengindikasikan apabila terjadi peningkatan atau penambahan dalam satuan satuan persepsi (X3) akan berakibat pada peningkatan keputusan konsumen milenial (Y) sebesar 0,700. 


\section{8) Uji Hipotesis}

\section{Uji Parsial atau uji t}

Uji parsial yang digunakan pada riset ini memakai uji thitung, dengan dasar pengambilan keputusan apabila thitung > ttabel maka asumsi dapat diakui. Nilai thitung bisa diamati pada tabelpengujian regresi dan nilai ttabel diperoleh dengan nilai signifikansi alpha sebesar $0,05(5 \%)$.

Tabel 9

Koefisien Hipotesis

\begin{tabular}{|c|c|c|c|c|c|c|}
\hline \multicolumn{2}{|c|}{ Model } & \multicolumn{2}{|c|}{$\begin{array}{l}\text { Unstandardized } \\
\text { Coefficients }\end{array}$} & \multirow{2}{*}{$\begin{array}{c}\text { Standardize } \\
\text { d } \\
\text { Coefficients }\end{array}$} & \multirow[t]{2}{*}{$\mathrm{t}$} & \multirow[t]{2}{*}{ Sig. } \\
\hline & & B & Std. Error & & & \\
\hline \multirow[t]{4}{*}{1} & (Constant) & 1.285 & 1.689 & & .761 & .44 \\
\hline & $\begin{array}{l}\text { Literasi Keuangan } \\
\text { Syariah }\end{array}$ & .063 & .030 & .143 & 2.082 & $\begin{array}{r}.03 \\
9\end{array}$ \\
\hline & Religiusitas & .196 & .057 & .237 & 3.435 & $\begin{array}{r}.00 \\
1\end{array}$ \\
\hline & Persepsi & .700 & .118 & .439 & 5.923 & $\begin{array}{r}.00 \\
0\end{array}$ \\
\hline
\end{tabular}

Sumber: Data diolah, 2021

Bersumber pada hasil pengujian parsial diatas diperoleh nilai t tabel yaitu 1,973 Berikut ini merupakan penjabaran hasil pengujian parsial:

1. Bersumber pada variabel literasi keuangan syariah $\left(\mathrm{X}_{1}\right)$, diketahui $t$ tabel sebesar $1,973<\mathrm{t}$ hitung 2,082 dan derajat penerimaan $0.039<0,05$, yang berarti bahwa variabel literasi keuangan syariah (X1) berpengaruh terhadap keputusan konsumen milenial (Y).

2. Berdasar pada hasil uji parsial variabel variabel religiusitas $\left(X_{2}\right)$, diketahui t tabel sebesar 1,973<t hitung 3,435 dan derajat penerimaan $0.001<0,05$, sehingga bisa diartikan bahwa variabel variabel religiusitas $\left(\mathrm{X}_{2}\right)$ berpengaruh terhadap keputusan konsumen milenial $(\mathrm{Y})$.

3. Berdasarkan pada hasil uji t variabel persepsi (X3) dapat diketahui bahwa t tabel sebesar 1,973 < thitung 5,923 dan nilai signifikansi 0,000 < 0,05, hasil menunjukan 
bahwa variabel persepsi (X3) memiliki pengaruh secara parsial terhadap keputusan konsumen milenial (Y).

\section{Uji Simultan atau uji F}

Prosedur pengujian simultan dimaksudkan agar mengetahui ada korelasi diantara setiap variabel dalam penelitian baik bebas maupun terikat secara bersamaan. Pengujian simultan ini memakai nilai distribusi $\mathrm{F}$ menggunakan pembandingan diantara Fhitung dan Ftabel pada derajat kepercayaan 95\% atau 0 = 5\%, adapun hasil analisisnya sebagai berikut:

Tabel 10

Uji F (simultan)

\begin{tabular}{|rl|r|r|r|r|r|}
\hline \multicolumn{2}{|c|}{ Model } & \multicolumn{1}{c|}{$\begin{array}{c}\text { Sum of } \\
\text { Squares }\end{array}$} & \multicolumn{1}{c|}{ df } & \multicolumn{1}{c|}{$\begin{array}{c}\text { Mean } \\
\text { Square }\end{array}$} & F & Sig. \\
\hline \multirow{2}{*}{1} & Regression & 879.398 & 3 & 293.133 & 61.243 & $.000^{\mathrm{b}}$ \\
& Residual & 847.188 & 177 & 4.786 & & \\
& Total & 1726.586 & 180 & & & \\
\hline
\end{tabular}

Sumber: Data diolah, 2021

Bersumber pada data hasil uji simultan diperoleh bahwa nilai $\mathrm{F}$ tabel adalah 2,66 dari tabel 30 dan nilai $\mathrm{f}_{\text {hitung }} 61.243>\mathrm{f}$ tabel 2,66 serta tingkat penerimaan dibawah 0,05. Berlandaskan pada prosedur pengujian diatas dapat dikatakan bahwa variabel literasi keuangan syariah, religiusitas, dan persepsi memiliki pengaruh bersamaan terhadap keputusan konsumen milenial dalam menggunakan produk dan jasa perbankan syariah.

\section{I.6 Pengaruh Literasi Keuangan Syariah Terhadap Keputusan Menggunakan}

\section{Layanan Perbankan Syariah}

H1: X1 berpengaruh positif dan signifikan terhadap Y.

Berdasarkan data pada variabel literasi keuangan syariah (X1) dengan nilai regresi 0,063X1, diketahui t tabel sebesar 1,973 < t hitung 2,082 dan nilai signifikansi $0.039<0,05$ yang artinya variabel literasi keuangan syariah (X1) berpengaruh terhadap keputusan menggunakan layanan perbankan syariah (Y). Hasil penelitian ini mendukung penelitian sebelumnya yang dilakukan oleh Rachmatulloh yang menyatakan bahwa semakin baik tingkat literasi keuangan generasi milenial maka akan semakin baik pula keputusan menabung yang diambil oleh mereka ${ }^{21}$. Kemudian penelitian ini juga menjawab kontadiksi

${ }^{21}$ Rachmatulloh, "Pengaruh Literasi Keuangan Syariah, Religiusitas Dan Kualitas Pelayanan Terhadap Keputusan Menabung Di Bank Syariah (Studi Pada Generasi Milenial Di Indonesia).” 
yang terjadi pada penelitian sebelumnya seperti penelitian Octavia yang menyatakan bahwa variabel literasi keuangan syariah tidak berpengaruh secara signifikan terhadap keputusan konsumen 22 .

\section{I.7 Pengaruh Religiusitas Terhadap Keputusan Menggunakan Layanan Perbankan Syariah}

H2: X2 berpengaruh positif dan signifikan terhadap Y.

Hal ini dapat dibuktikan dengan nilai regresi variabel religiusitas (X2) 0,196X2, diketahui t tabel sebesar 1,973 < t hitung 3,435 dan nilai signifikansi $0.001<0,05$ yang artinya variabel variabel tersebut berpengaruh terhadap menggunakan layanan perbankan syariah (Y). Berdasarkan hasil tersebut mengindikasikan bahwa dengan semakin meningkatnya tingkatan religiusitas seseorang maka akan semakin memengaruhi keputusannya dalam menggunakan layanan perbankan syariah. Aspek keagamaan seperti dimensi spiritual menjadi salah satu faktor yang mendorong keputusan tersebut. Penelitian ini mendukung penelitian sebelumnya yang dilakukan oleh Ilfita yang menyatakan bahwa semakin tinggi tingkat religiusitas seseorang, maka hal tersebut akan turut memengaruhi keputusannya dalam menggunakan perbankan syariah ${ }^{23}$, kemudian Iskamto yang menyatakan bahwa religiusitas berpengaruh secara signifikan terhadap kepercayaan kepada bank syariah ${ }^{24}$, serta Zuhirsyan yang menyatakan bahwa religiusitas yang baik atau tinggi akan berpengaruh terhadap semakin tinggi nasabah dalam mengambil keputusan memilih bank syariah ${ }^{25}$.

Penelitian ini pun menjawab pertentangan yang terjadi pada penelitian sebelumnya yang dilakukan oleh Yulianto yang menyatakan bahwa variabel religiusitas tidak berpengaruh signifikan terhadap keputusan penggunaan bank syariah ${ }^{26}$.

\section{I.8 Pengaruh Persepsi Terhadap Keputusan Menggunakan Layanan Perbankan} Syariah

H3 : X3 berpengaruh positif dan signifikan terhadap Y

22 Octavia, PENGARUH LITERASI KEUANGAN SYARIAH DAN PEMASARAN TERHADAP PENGAMBILAN KEPUTUSAN NASABAH MELAKUKAN PEMBIAYAAN MIKRO DI BANK WAKAF MIKRO MAWARIDUSSALAM, vol. 53, p. .

${ }^{23}$ Clarashinta Canggih Khoiriyah Ilfita, "THE INFLUENCE OF SHARIA FINANCIAL LITERACY, RELIGIOSITY, AND PERCEPTION OF SAVING STUDENTS' INTEREST IN SHARIA BANKS" 3, no. 2 (2021): 113-134.

24 Iskamto, "Analisis Peranan Religiusitas Terhadap Kepercayaan Kepada Perbankan Syariah."

25 Zuhirsyan, "Pengaruh Religiusitas Dan Persepsi Nasabah Terhadap Keputusan Memilih Bank Syariah."

${ }^{26}$ Agus Yulianto, "PENGARUH LITERASI KEUANGAN SYARIAH TERHADAP KEPUTUSAN PENGGUNAAN PRODUK ATAU LAYANAN LEMBAGA KEUANGAN SYARIAH” (2018): 121. 
Berdasarkan hasil yang diperoleh dari pengujian variabel persepsi terhadap keputusan menggunakan layanan perbankan syariah adalah positif dan signifikan, hal ini dapat dibuktikan melalui data regresi 0,700X3. Bersumber pada hasil regresi diketahui t tabel sebesar $1,973<\mathrm{t}$ hitung 5,923 nilai signifikansi $0,000<0,05$ yang artinya variabel persepsi (X3) berpengaruh terhadap keputusan menggunakan layanan perbankan syariah (Y).

Penelitian ini pun mendukung hasil penelitian sebelumnya seperti yang dilakukan oleh Ilfita yang menyatakan bahwa persepsi berpengaruh secara positif dan signifikan terhadap keputusan menabung di bank syariah ${ }^{27}$. Penelitian ini pun menjawab perbedaan hasil penelitian yang telah dilakukan sebelumnya oleh Zuhirsyan yang menyimpulkan bahwa variabel persepsi tidak berpengaruh secara signifikan terhadap keputusan memili bank syariah $^{28}$.

\section{I.9 Pengaruh Literasi Keuangan Syariah, Religiusitas dan Persepsi Secara} Simultan Terhadap Keputusan Menggunakan Layanan Perbankan Syariah

$\mathrm{H}_{1,2,3}$ : Variabel X1, X2 dan X3 secara simultan berpengaruh positif dan signifikan terhadap variabel $Y$.

Bersumber pada data dalam penelitian ini didapatkan informasi hasil pengujian simultan yang positif dan signifikan antara variabel literasi keuangan syariah, religiusitas dan persepsi terhadap keputusan menggunakan layanan perbankan syariah. Hasil ini dapat dibuktikan melalui nilai $f$ hitung sebesar $61.243>\mathrm{f}$ tabel 2,66 dan nilai sig. sebesar 0,000< 0,05. Berdasarkan hasil dari pengujian tersebut dapat dikatakan variabel literasi keuangan syariah (X1), religiusitas (X2), dan persepsi (X3) berpengaruh secara simultan terhadap keputusan menggunakan layanan perbankan syariah (Y).

\section{PENUTUP}

\section{Simpulan}

Dari uraian diatas maka dapat diambil kesimpulan:

1) Bersumber pada penjabaran telaah informasi yang telah diperoleh pada penelitian ini, maka dapat peneliti simpulkan bahwa variabel literasi keuangan syariah berpengaruh secara positif dan signifikan terhadap keputusan menggunakan layanan

27 Khoiriyah Ilfita, "THE INFLUENCE OF SHARIA FINANCIAL LITERACY, RELIGIOSITY, AND PERCEPTION OF SAVING STUDENTS' INTEREST IN SHARIA BANKS."

28 Zuhirsyan, "Pengaruh Religiusitas Dan Persepsi Nasabah Terhadap Keputusan Memilih Bank Syariah.” 
perbankan syariah. Hasil ini menunjukan bahwa semakin tinggi tahapan literasi keuangan syariah seseorang, maka akan semakin besar pula peran variabel tersebut dalam memengaruhi keputusan menggunakan layanan perbankan syariah.

2) Variabel religiusitas memiliki pengaruh yang positif dan signifikan terhadap keputusan menggunakan layanan perbankan syariah. Fenomena ini mengindikasikan bahwa semakin baik tingkat religiusitas seseorang, maka dapat disimpulkan bahwa faktor tersebut dapat memengaruhi keputusan menggunakan layanan perbankan syariah. Aspek keagamaan seperti dimensi spiritual menjadi salah satu faktor yang mendorong keputusan tersebut.

3) Variabel persepsi berpengaruh secara positif dan signifikan terhadap keputusan menggunakan layanan perbankan syariah, hal ini mengindikasikan bahwa semakin besar persepsi yang diterima oleh mahasiswa, oleh karena itu faktor tersebut akan memengaruhi keputusan mereka dalam menggunakan layanan perbankan syariah.

4) Literasi keuangan syariah (X1), religiusitas (X2) dan persepsi (X3) secara bersamaan memiliki pengaruh yang positif dan signifikan terhadap keputusan menggunakan layanan perbankan syariah (Y). Berdasarkan hasil uji simultan tersebut, ditemukan hubungan antara variabel bebas terhadap variabel terikat yang menunjukan bahwa keputusan menggunakan layanan perbankan syariah dapat dipengaruhi dari berbagai variabel, dalam penelitian ini dapat diambil determinasi bahwa literasi keuangan syariah yang mumpuni, tingkat religiusitas yang tinggi dan persepsi yang baik terhadap perbankan syariah mampu menjadi magnet dalam pengambilan keputusan dalam menggunakan layanan perbankan syariah.

\section{Saran}

1) Peneliti mengharapkan adanya perhatian khusus dari para manajemen bank syariah untuk memperluas lagi ragam produk dan jasa yang ditawarkan, agar masyarakat dapat lebih nyaman menggunakan layanan yang sesuai dengan keinginan mereka. Selain itu, manajemen perbankan syariah pun dapat menyoroti beberapa variabel yang berbeda dari penelitian ini seperti: ketersediaan jaringan dan teknologi, lokasi bank, mutu pelayanan, reputasi, fasilitas yang ditawarkan, biaya dan masih banyak lagi.

2) Saran dari peneliti kepada pihak regulator adalah pemerintah perlu memfasilitasi forum diskusi dengan berbagai pihak dan lembaga seperti pengusaha, organisasi, 
komunitas, maupun para akademisi secara berkesinambungan dalam merumuskan kebijakan yang ideal bagi keberlanjutan sistem ekonomi syariah, salah satunya adalah dengan memprioritaskan RUU Ekonomi Syariah untuk masuk kedalam Program Legislasi Nasional (Prolegnas) agar menjadi payung hukum yang lebih komprehensif dan solid untuk menciptakan ekosistem ekonomi syariah yang lebih maju.

3) Rekomendasi dari peneliti untuk penelitian yang akan datang sebaiknya perlu dilakukan penyebaran kuesioner dengan target responden yang lebih luas lagi agar dapat memberikan data dan variabel yang lebih beragam. Penambahan variabel dapat meliputi faktor pengaruh eksternal, faktor kesantunan dan keprofesionalan pegawai bank, faktor syariah, rasionalitas nasabah dan daya tarik fisik. 


\section{DAFTAR PUSTAKA}

Chaplin. Kamus Psikologi Lengkap. PT. Raja Grafindo Persada, Jakarta, 2008.

Fajar Mujaddid, Pandu Tezar Adi Nugroho. "PENGARUH PENGETAHUAN, REPUTASI, LINGKUNGAN DAN RELIGIUSITAS TERHADAP MINAT PELAJAR SEKOLAH MENENGAH KEJURUAN PRODI PERBANKAN SYARIAH DALAM MENABUNG DI BANK SYARIAH." Jurnal Ekonomi Islam 10 (2019).

Gujarati, and Porter. Dasar-Dasar Ekonometrika. 5th ed. Salemba Empat, 2015.

Harahap, Novia Melati. ANALISIS FAKTOR-FAKTOR YANG MEMPENGARUHI MINAT GENERASI MILENIAL JABODETABEK MEMILIH BANK SYARIAH. Malaysian Palm Oil Council (MPOC). Vol. 21, 2020. http://mpoc.org.my/malaysian-palm-oil-industry/.

Iskamto, Dedi. "Analisis Peranan Religiusitas Terhadap Kepercayaan Kepada Perbankan Syariah" (n.d.).

Kasmir. Bank Dan Lembaga Keuangan Syariah. PT. Raja Grafindo Persada, Jakarta, 2009.

Khoiriyah Ilfita, Clarashinta Canggih. "THE INFLUENCE OF SHARIA FINANCIAL LITERACY, RELIGIOSITY, AND PERCEPTION OF SAVING STUDENTS' INTEREST IN SHARIA BANKS" 3, no. 2 (2021): 113-134.

Khosasi, Akhsanul. "Pengaruh Literasi Keuangan Syariah Dan Pemasaran Terhadap Pengambilan Keputusan Nasabah Melakukan Pembiayaan Mikro Di Bank Syariah Bukopin Sidoharjo" (2017): 1-93.

Octavia, Anggraini. PENGARUH LITERASI KEUANGAN SYARIAH DAN PEMASARAN TERHADAP PENGAMBILAN KEPUTUSAN NASABAH MELAKUKAN PEMBIAYAAN MIKRO DI BANK WAKAF MIKRO MAWARIDUSSALAM. Journal of Chemical Information and Modeling. Vol. $53,2020$.

Rachmatulloh, Dhepril Puradi. "Pengaruh Literasi Keuangan Syariah, Religiusitas Dan Kualitas Pelayanan Terhadap Keputusan Menabung Di Bank Syariah (Studi Pada Generasi Milenial Di Indonesia)" (2020).

Shandy Utama, Andrew. "Perkembangan Perbankan Syariah Di Indonesia." UNES Law Review 2, no. 3 (2020): 290-298.

Shobah, Nurus. "Analisis Literasi Keuangan Syariah Terhadap Penggunaan Jasa Perbankan Syariah Sebagai Upaya Meningkatkan Sharia Financial Inclusion(Studi Pada Mahasiswa Ekonomi Syariah UIN Sunan Ampel Surabaya)." UIN Sunan Ampel Surabaya (2017).

Siswoyo, Dwi. Ilmu Pendidikan. Yogyakarta: UNY Press, 2007.

Sobur, Alex. Psikologi Umum. Pustaka Setia, Bandung, 2003.

Uma Sekaran, Roger Bougie. Metode Penelitian Untuk Bisnis. 6th ed. Salemba Empat, 2017.

Yulianto, Agus. "PENGARUH LITERASI KEUANGAN SYARIAH TERHADAP KEPUTUSAN PENGGUNAAN PRODUK ATAU JASA LEMBAGA KEUANGAN SYARIAH" 10, no. 2 (October 2018): 1-15. 
- - - "PENGARUH LITERASI KEUANGAN SYARIAH TERHADAP KEPUTUSAN PENGGUNAAN PRODUK ATAU LAYANAN LEMBAGA KEUANGAN SYARIAH” (2018): 121.

Yusuf, Syamsu. Psikologi Perkembangan Anak Dan Remaja. Bandung: Remaja Rosdakarya, 2012.

Zuhirsyan, Muhammad. "Pengaruh Religiusitas Dan Persepsi Nasabah Terhadap Keputusan Memilih Bank Syariah” 10, no. 1 (2018): 48-62. 